\title{
ETIKA POLITIK TERHADAP PERILAKU KORUPSI DI INDONESIA (Studi Kasus DPRD Kota Malang)
}

\author{
Ashari Sakti Alim ${ }^{1}$, Salmawati ${ }^{2}$, Dian Eka Rahmawati ${ }^{3}$ \\ Magister Ilmu Pemerintahan, Pascasarjana, Universitas Muhammadiyah Yogyakarta. \\ Ilmu Pemerintahan, FISIP, Universitas Muhammadiyah Sorong. \\ Magister Ilmu Pemerintahan, Pascasarjana, Universitas Muhammadiyah Yogyakarta.
}

*Korespondensi: ganhysalma027@gmail.com

\begin{abstract}
This journal discusses political ethics that can influence corrupt behavior in Indonesia and more specifically in the legislature. To answer the formulation of the problem in this study, the authors use the library research method by conducting an in-depth study through journals, books and social media. The results of this study showed that 41 of 45 members including the chairman of the Malang City DPRD had to deal with the KPK related to bribery cases. Regarding corruption, not only do we understand the loss to the state, but it is an ethical problem, a moral problem, a behavioral problem and a national problem. The death of political ethics makes deviant behavior of stakeholders and also freezes political ethics among elites makes many big surprises that can be seen with so much corruption in a country.
\end{abstract}

Kata kunci: etika politik, perilaku korupsi, Indonesia

\begin{abstract}
ABSTRAK
Jurnal ini membahas tentang etika politik yang dapat mempengaruhi perilaku korupsi di Indonesia dan lebih khusus lagi di lembaga legislatif. Untuk menjawab rumusan masalah dalam penelitian ini, maka penulis menggunakan metode penelitian pustaka dengan melakukan studi mendalam melalui jurnal, buku dan media sosial. Hasil penelitian ini menunjukan 41 dari 45 anggota termasuk ketua DPRD kota malang harus berurusan dengan KPK terkait kasus suap. Mengenai korupsi bukan hanya kita memahami kerugian negara, tetapi ini adalah masalah etika, masalah moral, masalah perilaku dan masalah nasional. Kematian etika politik membuat perilaku menyimpang dari para pemangku kepentingan dan juga membekukan etika politik di antara para elit membuat banyak kejutan besar yang dapat dilihat dengan begitu banyaknya korupsi dalam suatu negara.
\end{abstract}

Keywords: political ethics, corruption behavior, Indonesia

\section{PENDAHULUAN}

Paper ini ingin mendiskusikan bagimana etika politik bisa mempengaruhi terhadap perilaku korupsi yang ada di indonesia dan lebih khususnya di lembaga legislatif. Dimana Etika berbicara mengenai kebaikan manusia sebagai manusia, politik berbicara mengenai manusia secara keseluruhan atau dimensi kolektif dari kemanusiaan. Jadi dengan etika politik berarti bahwa pertama kita harus baik sebagai pribadi manusia tapi 
disaat yang pertama harus baik saat menjadi warga negara. Baik sebagai manusia saja tidak cukup karna manusia yang baik di dalam negara yang buruk akan bisa ikut buruk. Sebaliknya manusia yang buruk tapi di kehidupan negara yang relatif baik maka bisa ikut ikutan baik. Maka dari itu pribadi harus baik dan bernegara juga harus baik.

Pribadi yang kuat secara etik bisa di bangun melalui agama, bisa dibangun oleh kearifan kearifan, sayangnya agama kita saat ini tidak menyamai dengan etika itu adalah realita yang sekarang. Mestinya prasyarat baik bisa menyemai agama dan adat istiadat. Tapi untuk menjadi warga negara yang baik, harus memiliki kecerdasaan kewarganegaraan. Menjadi warga negara yang baik sebenarnya sudah terkandung dalam kata kata politik itu sendiri. Sebenarnya politik itu didalamnya ada prasyarat etik, oleh karna itu basis pertama dalam politik adalah sebenarnya budaya kewarganegaraan. Di dalam politik setiap orang harus menyadari bahwa dia sebagai warga negara dan oleh karna itu harus siap mengembang kewajiban kewargaan harus mengerti hak dan kewajiban bernegara.

Bagi masyarakat indonesia etika politik yang pertama yang harus di darahi adalah keterampilan untuk bisa bersatu di dalam keragaman. Jadi bagi orang indonesia yang tidak bisa bergaul dalam keragaman adalah bukan sepenuhnya indonesia, jadi warga negara harus bisa bergabung di dalam keragaman dalah basis etika yang paling dasar bagi warga negara indonesia. Tujuan etik yang paling utama adalah membuat kebahagiaan. Yang diperkuat dari etika politik di indonesia saat ini adalah landasan kebahagiaan adalah pancasila. Politik bukan semata mata bagaimana mendapatkan kekuasaan, politik adalah bagaimana dalam menyelesaikan persoalan bersama, memberi manfaat bagi orang banyak, dan bisa membuat hidup lebih sejahtera. Tapi dalam 20 tahun terakhir ada banyak sekali sikap politik di indonesia secara struktural mengalami perubahan yang cukup drastis dan menimbulkan ide ide mengambil alih reformasi yang telah di bangun selama 20 tahun terakhir.

Salah satu masalah yang sekarang dihadapi adalah masalah etika politik karna belum ada tanda tanda bahwa kalangan politisi atau politik saat ini bisa mengukuti, bisa mentaati, bisa menjalankan, bisa membumikan etika politik itu. Karna sampai sekarang belum terlihat tanda tanda yang meyakinkan. Hal ini bisa dilihat dengan belum tercapainya keseimbangan 
di antara kekuatan kekuatan politik yang ada saat ini dan bahkan ada juga kaitannya dengan konsolidasi demokrasi yang belum selesai di indonesia ini dan yang paling pentingnnya belum terbentuknya kultur budaya demokrasi di tanah air ini. Bisa dilihat dengan masih merajalelanya oligarki atau kekuasaan oleh elit itulah yang membuat gejolak publik terhadap sistem demokrasi sebuah pemerintahan atau rezim. Maka etika publik harus di jalankan secara keseluruhan termaksud etika politik itu atau sederhananya yaitu bisa menjalankan mana yang baik dan tidak menjalankan mana yang buruk. Karena dalam sistem demokratisasi menerapkan tatanan kehidupan masyarakat yang adil dan merata.

Etika politik memiliki fungsi yang sangat penting dalam mendorong praktik reformasi dalam tata kelola pemerintahan melalui penegakan integritas dan nilai etika. Karena dalam praktiknya Para pemimpin menjalankan wewenang jika mereka dapat memberikan alasan pembenaran bagi hak mereka berkuasa atas orang lain. Membuat kebijakan berkaitan erat dengan hak moral untuk menentukan kebijakan, membuat penilaian, mengeluarkan perintah dan menyelesaikan konflik. Umumnya prinsip-prinsip etika politik yang memberikan pembenaran pada wewenang cenderung lebih spesifik daripada nilai-nilai umum. Wewenang lebih banyak memiliki aspek subjektif daripada kekuasaan. Kebanyakan tipe kekuasaan menunjukkan sumber daya yang relatif objektif dan nyata, Dalam kaitan ini, para aktor pemerintah dalam mengelola pemerintahannya dengan normatif yang lebih menekankan pada keyakinankeyakinan dan prinsip-prinsip moral guna menetapkan hak membuat keputusankeputusan dan menerapkan kewajibankewajiban. Seorang pemimpin yang mengaku memiliki etika berpolitik untuk berkuasa, ia dapat memperoleh wewenang dari sumber-sumber yang dapat digunakan dengan efektif.

Di era reformasi pemerintahan penyelenggaraan negara telah terjangkit virus korupsi baik atasan maupun bawahan. Secara tradisional korupsi dalam istilah individu pejabat publik yang menyalahgunakan jabatan publik untuk keuntungan pribadi. Tetapi korupsi memiliki jangkauan yang lebih luas. Ini adalah gejala kegagalan institusional yang mahal, seringkali melibatkan jaringan politisi, organisasi, perusahaan, dan individu swasta yang berkolusi untuk mendapatkan manfaat dari akses ke kekuasaan, sumber daya publik, dan pembuatan kebijakan dengan 
mengorbankan barang publik maka itu sangat dibutuhkan reformasi dalam suatu negara. Reformasii yaitu usaha yang terstruktur, terarah secara menyeluruh untuk mengaplikasikan sistem pengelolaan pemerintahan dengan sangat baik. Selain political ethics adalah etika berpolitik dalam aturan yang mungkin menjadikan tataran cara menyelenggaraan pemerintah yang baik dengan mengawal persatuan yang yang membangun dan normatif di bagian pemerintahan, bagian swsta dan masyarakat.

Salah satu kasus yang real kegagalan dalam reformasi tata kelola di indonesia adalah banyaknya korupsi di tubuh lembaga eksekutif, legislatif dan yudikatif yang Mengakibatkan munculnya banyak masalah seperti korupsi, kelompok nepotisme juga susah di berantas, dan juga peraturan hukum susah dijalankan, pengaturan dalam hal ekonomi, juga adanya pelayanann kepada masyarakt yang tidak baik. perilaku Korupsi dapat dilihat sebagai perilaku yang tidak bermoral atau perilaku yang tidak mematuhi prinsip. Bisa juga suatu perbuatan dilaksanakan dengan tujuan untuk menyalurkan keuntungan. Tidak sama dengan resmi dan hak dari pihak lain dan dengan salahkan menyalahgunakan jabatannya untuk memperkaya diri sendiri. Dalam negara demokrasi baru indentik dengan korupsi yang parah karena demokratisasi di bentuk untuk melawan pemerintahan otokratis, tetapi dalam pada masa reformasi hanya sebatas aturan atau sistem tanpa disertai oleh substansi yang kuat. Sehingga ketidak stabilan demokrasi membuat korupsi yang parah.

Berangkat dari masalah tersebut penulis ingin menganilis secara mendalam. "apakah adanya pengaruh dari etika politik terhadap perilaku korupsi di indonesia, khususnya di lembaga legislatif'. Tujuan dari menulis paper ini adalah penulis ingin mengetahui berlaku atau tidakah etika politik terhadap perilaku korupsi di indonesia khususnya di lembaga legislatif, dan diharapkan dengan adanya etika dalam berpolitik bisa mengikis perilaku seorang dalam melakukan tindakan korupsi yang dapat merugikan banyak orang.

\section{METODE}

Untuk menjawab rumusan masalah dalam penulisan ini, maka penulis menggunakan metode penelitian library researce yaitu melakukan kajian yang mendalam melalui jurnal, buku dan media sosial, selanjutnya di gunakan untuk mendeskripsikan titik temu bagaimana etik politik bekerja dalam perilaku korupsi 
sehingga dapat terlaksananya etika politik yang bermatabat dan berkeadilan.

\section{HASIL DAN PEMBAHASAN}

\section{Etika Politik di Indonesia}

Etika sangat erat kaitanya dengan kehidupan manusia, etika berkaitan dengan karakter dan moral. Etika berkaitan dengan baik dan buruk, benar atau salah, etika menjadi pengontrol atas aktivitas manusia melalui karakteria nilai negatif dan positif (Runi, 2017). Dengan demikian etika menjadi pedoman perilaku dalam kehidupan berbangsa dan bernegara. Dalam konteks politik, etika berkaitan dengan penerapan prinsip moral terhadap perilaku pejabat dalam orgonisasi publik. Etika politik secara luas mencukup standar, aturan, norma dan ajaran yang berhubungan dengan peran dan fungsi jabatan politik dalam menjalankan fungsi pelayanan dan memenuhi tanggung jawab yang terkait dengan sumpah jabatan. Lebih dari itu etika politik soal penilaian moral atada tindakan politik dan agenda politik.

Politik yaitu konsep etika etika selalu ampuh dalam mewujudkan nilai-nilai pencerahan selanjutnya (Shapiro, 2014). Bisa dibilang, etika adalah keharusan untuk dunia mukhtahir, tradisi budaya dalam bentuk etika mengusulkan tawaran yang jauh lebih unggul dari pada kebiasan pemikiran yang lain mengakibatkan para pelaku politik di kawasan masyarakat yaitu hak seseorang adalah bentuk terbaik. Dimana etika politik dalam kehidupan bangsa dan bernegara adalah upaya manusia untuk menjadi lebih baik.

Dalam buku etika diruang publik (Abas, 2017) menjelaskan bahwa etika politik secara luas mencakup standar, aturan, norma dan ajaran yang berhubungan dengan peran dan fungsi jabatan politik dalam menjalankan fungsi pelayanan dan memenuhi tanggung jawab yang terkait dengan sumpah jabatan. Artinya etika politik terlibat dalam hal membuat penilaian moral tentang tindakan politik dan agenda politik. Politik dalam konteks etika perlu didefinisikan, sebab terjadi perbedaaan pemahaman tertang politik pada umumnya, khusus dalam konteks prespektik deskriptif yakni hanya sekedar mengajar atau mempertahankan kepentingan dan kekuasaan melalui berbagai cara . istilah politik dalam konteks etika normatif umumnya menunjuk pada posisi masyarakat secara keseluruhan. Artinya sebuah keputusan di anggap bersifat politis apabila keputusan tersebut di ambil dengan memperhtikan kepentingan masyarakat secara keseluruhan. Suatu tindakan dianggap 
politis apabila menyangkuut masyarakat secara keseluruhan. Sendangkan politisi adalah seorang yang mempunyai profesi mengenai masyarakat sebagai keseluruhan. Dengan demikian, etik politik itu merupakan filsafat moral tentang demensi politis kehidupan manusia.

Menurut (Smith \& Al, n.d.), tetapi tunduk pada variabilitas dinamis tingkat individu yang cukup. Hipotesis Perubahan Moral Yayasan Akan Memprediksi Perubahan Sikap Politik Jika fondasi moral secara kausal memengaruhi ideologi politik, secara logis bukan saja seharusnya fondasi moral pada saat itu meramalkan fondasi moral, dan ideologi politik pada tl seharusnya memprediksi ideologi pada budaya, tetapi yang lebih penting, perubahan ideologi pada t2 juga harus dimediasi melalui perubahan dalam fondasi moral. Lebih sederhana lagi, jika dasar moral menyebabkan ideologi politik, perubahan fondasi moral harus sesuai dengan perubahan ideologi politik. Arah hubungan kausal antara ideologi dan penalaran moral telah lama diperdebatkan (Emler, Renwick, dan Malone 1983). Weber dan Federico (2013, 125), misalnya, berdebat mendukung pengujian kausalitas timbal-balik khususnya antara fondasi moral dan ideologi. Meskipun fokus utama kami adalah pada dasar moral sebagai penyebab sikap politik, mengingat bahwa kami menemukan sikap politik jauh lebih stabil.

Selanjutnya dalam buku Etika dan Logika Berpolitik (A. Bakir Ihsan, 2016) Mengungkapkan bahwa demokrasi memastikan aturan demi aturan yang telah di atur. Bukan hanya aturan yang merangkaikan prosedur. Tapi juga kultur budaya di strukturkan. Karena itu, aturan sejatinya berjalin dengan kepatuhan warga negara, inilah etika pilitik dalam logika yang semestinya menjadi landasan berpolitik.

Dalam jurnal (Ritaudin, 2014) menyampaikan bahwa Etika politik di kehidupan berbangsa dan bernegara adalah upaya manusia untuk berpikir pada dasarnya tentang kebaikan dan kebijaksanaan menjalankan semua aspek dalam kehidupan berbangsa dan bernegara. Untuk menemukan jawabannya, bagaimana kehidupan yang baik di negara dan bangsa dapat diterapkan, etika politik tidak hanya berhubungan dengan kekuasaan dan sistemnya tetapi juga dengan kehidupan manusia. Karena itu, politik tidak dapat diberikan kepada politisi atau ilmuwan politik. Untuk itu diperlukan semacam paradigma kemanusiaan dan etika sebagai sikap dasar manusia yang 
dapat disepakati oleh semua warga negara. Artikel ini membahas tentang pentingnya etika politik dalam kehidupan berbangsa dan bernegara saat ini, terutama untuk negara seperti Indonesia.

Selanjutnya dalam buku Berani Korupsi itu Memalukan (Poernomo, 2013)menjelaskan bahwa nilai objek korupsi lazimny jauh lebih besar dibanding nilai hasil pencurian, bahkan perampokan. Nilai aksi kejahatan korupsi nisa milliaran, bahkan triliunan rupiah. Di samping itu, didalam korupsi selalu ada unsur penghianatan terhadap amanah, bahkan amanat ari orang banyak. Objek korupsi selalu berupa uang atau hal-hal berharga lin sebagai manat negara/rakyat keseluruhan yang ada di dalam tanggung jawab si koruptor.

Dalam jurnal (Kaufmann, 2016) menjelaskan Secara tradisional budaya korupsi didefinisikan dalam istilah individu. pejabat publik yang menyalahgunakan jabatan publik untuk keuntungan pribadi. Tetapi korupsi memiliki jangkauan yang lebih luas. Artinya Ini adalah gejala kegagalan institusional yang sangat berharga, karena seringkali melibatkan jaringan politisi, kelompok, perusahaan, dan individu swasta yang berkolusi untuk mendapatkan manfaat dari akses ke kekuasaan, sumber daya publik, dan pembuatan kebijakan dengan mengorbankan barang publik. Budaya Korupsi politik sistemik, khususnya yang terkait dengan dana kampanye dan elit (atau negara bagian) yang terkait - pengaruh yang tidak semestinya pada undang-undang, peraturan, dan kebijakan oleh kepentingan perusahaan yang kuat - menjangkiti banyak negara salah satunya adalah indonesia dan berpenghasilan menengah (dan demokratis) di seluruh dunia, termasuk di Utara, Tengah, dan Amerika Selatan. Dalam konteks penangkapan negara dan "korupsi hukum" ini sangat penting untuk mempertimbangkan pandangan alternatif korupsi.

Pada jural politik korupsi (Ceva \& Ferretti, 2018) Apakah perilaku korup pejabat publik jenis yang relevan secara politis hanya salah jika menyebabkan kegagalan fungsi institusi? Kami menantang pendekatan institusionalis barubaru ini terhadap korupsi politik dengan menunjukkan perasaan di mana perilaku korup individu pejabat publik tertentu salah tidak hanya sebagai pelanggaran moralitas pribadi, tetapi dalam hal yang secara inheren secara politis menonjol. Untuk menunjukkan pengertian ini, kami fokus pada contoh spesifik perilaku korup 
individu pada bagian pejabat publik yang dipercayakan dengan kekuatan untuk menerapkan aturan publik dalam demokrasi liberal. Meskipun tidak selalu melanggar hukum, perilaku mereka secara politis salah qua korup ketika bertentangan secara diam-diam persyaratan pembenaran publik yang menopang ketertiban umum. Kemudian, kami membedakan bentuk korupsi ini sebagai tindakan sembunyisembunyi dari jenis-jenis kelakuan politik yang melanggar hukum tetapi dibenarkan secara publik sebagai pembangkangan sipil.

Selanjutnya pada jurnal (Esarey \& Schwindt-bayer, 2016), coba menjelaskan bahwa Korupsi adalah ancaman politik yang diperangi oleh semua negara, dengan tingkat keberhasilan yang bervariasi. Dalam beberapa negara, tingkat korupsi rendah dan contoh dugaan korupsi dengan cepat dibawa ke pengadilan. Tuduhan baru-baru ini dari mantan gubernur Illinois Rod Blagojevich dan mantan walikota New Orleans Ray Nagin di Amerika Serikat mencontohkan hal ini. Korupsi adalah kegiatan berisiko bagi elit politik dalam situasi ini. Di negara-negara lain, seperti Meksiko dan Venezuela, tingkat korupsi masih tinggi dan kasus-kasus korupsi individu jarang menjadi berita utama atau menghasilkan konsekuensi negatif bagi mereka yang terlibat. Berpartisipasi dalam korupsi tidak terlalu berisiko di daerah-daerah ini dan bahkan mungkin menjadi cara yang elit memajukan karir politik mereka. Penelitian yang ada telah menemukan bahwa keterwakilan perempuan dalam pemerintahan dikaitkan dengan tingkat korupsi yang lebih rendah, membuat sebagian orang berpikir bahwa peningkatan pemilihan perempuan untuk jabatan akan mengurangi korupsi di negara-negara.

\section{Etika Politik DPRD Kota Malang}

Disini penulis ingin memberikan salah satu contoh kasus di Kota Malang, dimana kasus korupsi massal di Kantor DPRD Kota Malang dan jawa timur menunjukan bahwa tidak ada samasekali etika dalam berpolitik. Bukannya saling mengawasi lembaga eksekutif dan legislatif bersama-sama menggorogoti Dana APBD. Suap pendapatan Anggaran Pendapatan dan Belanja Daerah Perubahan atau APBP tahun 2015 menjadi kasus korupsi melibatkan anggota DPRD paling banyak. Dari kasus ini 41 dari 45 anggota termaksud ketua DPD kota malang harus berurusan dengan KPK. Selain 41 anggota DPRD kota malang, kasus korupsi ini juga melibatkan walikota malang muhammad 
anton yang di di tahan kpk, serta kepala dinas DPUDPB kota malang sulistiono. Dalam kasus ini bisa dinyatakan bahwa rusaknya etika dalam berpolitik dan juga hancurnya sistem kontrol antara lembaga eksekutif dan legislatif di kota malang dan sejujurnya kasus seperti ini tidak hanya terjadi di kota malang tapi juga terjadi di berbagai daerah di indonesia.

Lanjut penulis ingin membahas perilaku koruptif di lembaga legislatif, korupsi di tubuh lembaga wakil rakyat ini sudah masuk kategori gawat darurat, disebut darurat karena dari sepuluh operasi tangkap tangan atau lebih dikenal dengan OTT yang dilakukan oleh KPK, lima diantaranya melibatkan anggota legislatif komisi 3 bidang hukum, lima pelaku tersebut adalah ketua komisi, wakil ketua dan anggotanya, mereka adalah aktor yang bersidang di ruang pengadilan. Perilaku koruptif di lembaga legislatif ini sudah merangkuh sangat jauh dari tingkatan paling bawahan sampai ke atasan. hingga mencapai di puncaknya yaitu di Mahkama Agung atau MA sebagai benteng terakhir pencari keadilan. Kasus tersebut mencerminkan bahwa etika politik telah mati dan perilaku koruptif di tubuh lembaga legislatif sangat merajalela.
Dalam dua contoh kasus yang telah di paparkan di atas maka berbicara korupsi itu bukan hanya bagaimana kita memahami tentang kerugian negara. Tapi ini persoalan etika, persoalan moral, persoalan perilaku dan persoalan bangsa. penulis tidak bisa membayangkan bagaimana generasi berikutnya adalah generasi-generasi dimana cara berpikir, cara berkultur berbudaya dan sebagaimananya itu corruption atau korupsi yang artinya kotor. Oleh karna itu penulis sepakat kalau budaya korupsi haris dicegah dalam bentuk apapun. Karna persoalan korupsi itu bukan hanya persoalan kerugian negara. Karna kalau hanya itu adalah sederhana sekali. Tapi ini menyangkut dengan masalah yang lebih besar. Wakil Rakyat adalah pejabat dengan kasus korupsi terbanyak.

Gambar 1. Anggota DPR dan DPRD terjerat korupsi

Anggota DPR/DPRD Yang Terjerat Kasus Korupsi (2004-2018)

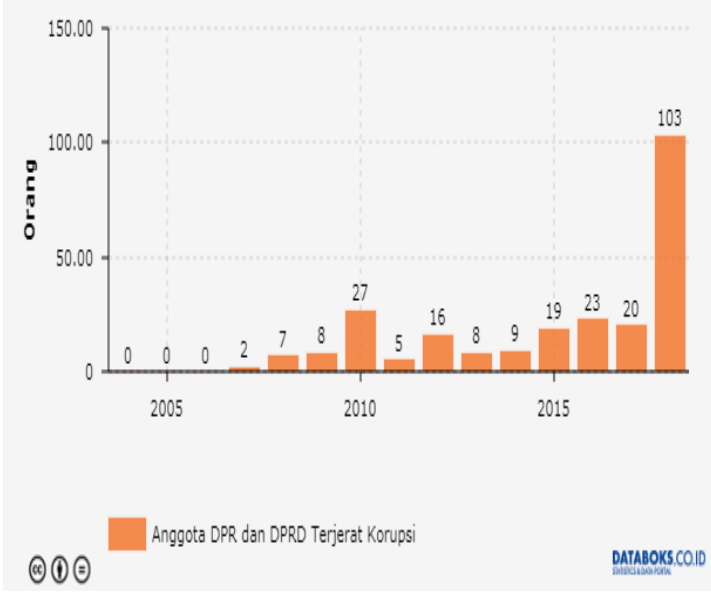

Sumber: Databoks.co.id 2018 
Ini adalah bukti bahwa dari tahun ketahun angka khasus korupsi di tubuh legislatif terus meningkat. Dan yang paling terbaru adalah pada tanggal 3 maret 2018, KPK berhasil melakukan operasi tangkap tangan di kantor agama sidoarjo, jawa timur. Dalam operasi tangkap tangan tersebut, KPK berhasil menyeret ketua umum partai persatuan pembangunan (PPP) yang juga sebagai anggota DPR yaitu Romahurmuziy terkait suap pengisian jabatan di kementerian agama. Dan juga anggota DPR yang berperan sebagai wakil rakyat justru yang paling banyak terjerat kasus korupsi.

Gambar 2. Tindak pidana korupsi berdasarkan profesi, 2004-2018

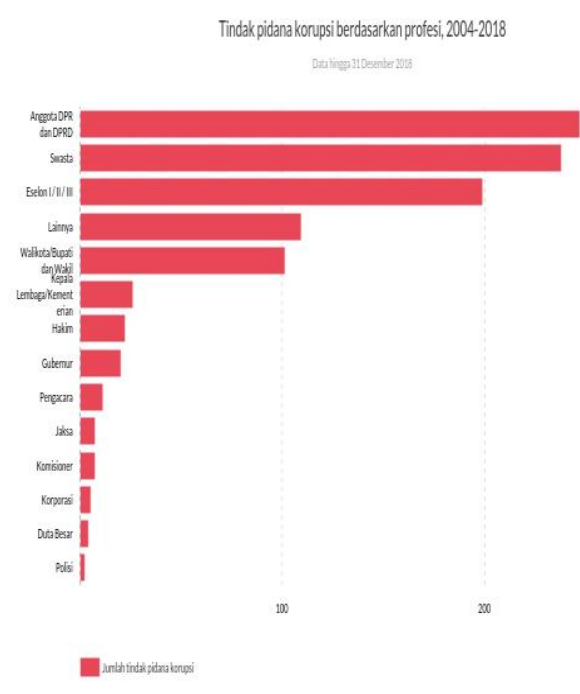

Sumber: Lokadata 2018

Berbicara persoalan perilaku, korupsi ini juga akhirnya menjadi budaya di indonesia dan itu menjadi sanggat mengkhawatirkan karna budaya korupsi ini sudah lama menggrogoti indonesia terutama di lembaga legislatif. Perilaku koruptif sangat mempunyai dampak kalu di ilustrasikan korupsi ini seperti gunung es, jadi puncaknya itu karna yang dilihat oleh masyarakat hanyalah puncaknya saja seperti kasus-kasus korupsi yang sudah sampai merugikan keuangan negara, kasus suap menyuap tapi masyarakat belum menyadari kalau ada ada persoalan yang lebih besar yaitu perilaku koruptif.

Berbagai macam teori-teori kriminologi konvensional tidak mampu menjelaskan. misalnya korupsi karna kejahatan konvensional kejahatn itu dilakukan karena kemiskinan, sudah tidak berlaku lagi bagi korupsi karna memang korupsi itu by design. Sejak awal memang sudah direncanakan, korupsi bukan lagi bagaimana seseorang yang melanggar hukum karna ini tentang maenset dan juga etika dalam berpolitik inilah yang semacam memerlukan rekonstruksi. Masyarakat di indonesia ini sudah dipengaruhi oleh budaya korupsi ini. Identitas dari bangsa indonesia inikan tentang nilai-nilai etika yang memang dan juga sudah menjadi harga mati yaitu pancasila. Sebenarnya kalau dikaji nilainilai etika leluhur adalah nilai-nilai tenang anti korupsi. Problemnya adalah tidak ada 
ruang kepada masyarakat indonesia untuk menginternalisasi dan mengaktualisasi. Ini juga balik kepada konsep bahwa membentuk budaya itu membutuhkan sosok atau figur yang teladan dalam memimpin. Jadi di indonesia ini kekurangan stok orang orang yang mempunyai etika dalam berpolitik. Masyarakat di indonesia masih sebagian besar sisi budaya patnerliastik disinilah yang menjadi urgennya. Seorang figur yang memang yang memang bersih dari persoalan persoalan itu tadi karna tidak bisa dilupakan kalau konteks budaya di indonesia memang seperti itu. Maka dibutuhkan sosok pemimpin yang memang bersih.

Gambar 3. Jumlah Pelaku Tindak Pidana Korupsi
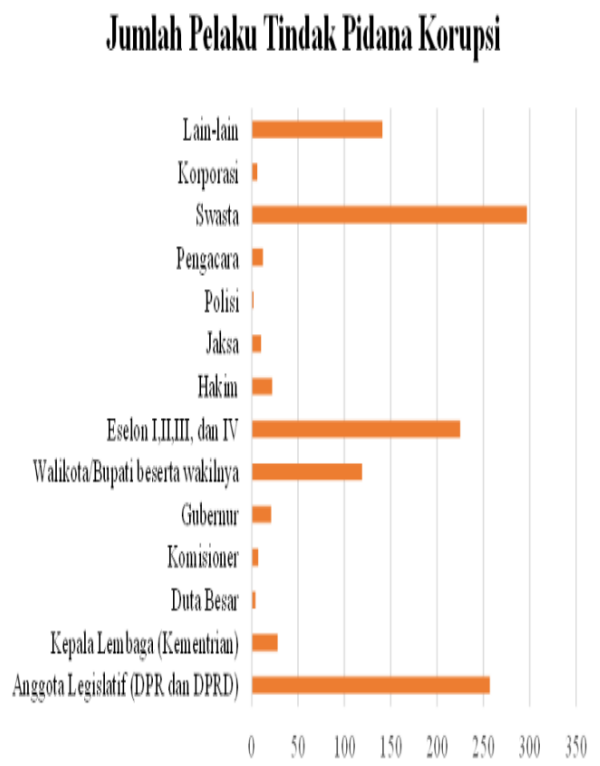

Sumber : Kumparan 2019
Kalau berbicara upaya memberantas perilaku korupsi itu harus memakai dua pendekatan besar. Yang pertama; adalah pendekatan sistem dan yang kedua adalah pendekatan individual nah ini menyangkut dengan etika politik seseorang. Pendekatan sistem ini ya hukumnya, penegakan hukumnya, sistem pendidikan, rekrutmen dan pengawasan. Bagaimana mengawasi pemerintahannya itu perlu di tata oleh sistem yang emang penting dan perlu untuk dilakukan. Dalam ini juga sangat penting karna dalam konteks memerlukan tokoh yang benar benar ingin memberantas korupsi. Oleh karna itu dibutuhkan seorang figur yang yang duduk di posisi-posisi tertnggi di pemerintahan ini memang harus baik.

Pancasila juga tidak bisa serta merta membuat habisnya korupsi dikarenakan dalam mengimplementasikan itu harus memeliku dua konsep. Yang Pertama, adanya dengan keteladan pemimpin. Peran penting pancasila menjadi filsafah bangsa akan mandul dan tidak bisa berfungsi sebagai dasar hukum serta kebijakan negara apabila tidak bisa berfungsi sebagai dasar hukum serta kebijakan negara apabila tidak disertai niat, sikap an perilaku penyelenggara negara serta tokoh bangsa lainnya. Suatu filsafah akan diikuti apabila disampaikan oleh seseorang yang berperan 
sebagai teladan dan panutan. Kalau pemimpin yang mengajarkan pelaksanaan pancasila dalam sikap dan perilaku koruptif, masyarakat tidak mungkin akan mengikutinya.

Kedua; pengunaan etika menjadi alat dalam pemberantasan korupsi akan sukses apabila di ikuti dengan konsep yang konkret, kepercayaan . contohnya, adanya perubahan sistem politik dan jga diterapkannya azaz pembuktiap terbalik dalam hukum nasional dan penerapan hukum mati bagi koruptor. Dengan demikian, maka tiba daatnya etaka dalam berpolitik disosialisakian kepada masyarakat, termaksut kepada para remaja dan juga bagi para penerus generasi selanjutnya.Penguatan etika dalam berpolitik ini tidak bisa di lepaskan dari ideologi dan konstitusi. Seluruh gerak politik yang dimainkan oleh para elite dan masyarakat harus berpegangan pada dua kerangka tersebut sebagai pegangan berbngsa dan bernegara bahkan dalah konteks global. Ketika dasar etika dalam logika berpolitik tidak sejalan, maka dalam menumpuk kebiasaan politik korupsi yang meresahkan masyarakat. Tingkat keresahan masyarakat yang tumbuh salah satunya adalah karena adanya apresiasi para elite atau aspirasi masyarakat. Publik betul betul dilibatkan dalam dalam proses pengambilan kebijakan dan kontrol atas adanya pemerintahan yang baik. Inilah sampai saat ini tidak tumbuh, sehinga etika politik hanya menjadi konsep perjudian kaum elite.

\section{SIMPULAN}

Dari hasil penulis artikel di atas dapat menyimpulkan bahwa Korupsi juga bertentangan dengan etika, nilai kemanusiaan, keadilan, serta adab mulia secara universal. Perilaku koruptif adalah manifestasi dari tumbuhnya sifat keserakahan pada diri sang pelaku. Seperti yng telah dijelaskan pada pembahasan diatas bahwa, Pengaruh dari etik politik terhadap perilaku korupsi di lembaga legislatif sangat besar. Hal ini di dukung oleh bukti-bukti yang ada seperti bukti dari KPK.

Dengan kejam dan rakus, sang pelaku mengambil sesuatu yang bukan haknya untuk kemewahan dirinya, atapun kelompoknya. Pelaku korupsi yang memperkaya diri, secara langsung ataupun secara tidak langsung, tentu jauh dari rasa persatuan dan kesatuan bangsa. Karena korupsi menjadi akar dari perpecahan atau konflik yang rusak persatuan dan kesatuan negeri ini. 
Matinya etika politik membuat perilaku menyimpang dari para pemangku kekuasaan dan juga membekukan etika politik di kalangan elite membuat banyak guncangan hebat, hal itu dapat dilihat dengan begitu banyaknya korupsi di negara ini. Mereka tidak siap dalam menjalani perubahan yang begitu besar sementara dilain sisi para elite juga masih terjebak oleh nilai kesadaran masa lalunya yang buruk. Hal itu mengakibatkan banyaknya ledakan ledakan anomalis yang mengakibatkan seseorang mengancam etika politik. Bisa di simpulkan bahwa betapa pentingnya etika dalam berpolitik, karna dengan etika yang baik bisa menghapus perilaku buruk seseorang (berkuasa).

\section{DAFTAR PUSTAKA}

A. Bakir Ihsan. (2016). Etika Dan Logika Berpolitik. (Anang SW., Ed.). Bandung: ROSDA.

Abas, A. (2017). Urgensi Etika Dalam Tata-Kelola Pemerintahan (Governance). JPSI (Journal of Public Sector Innovations), 1(2), 79. https://doi.org/10.26740/jpsi.v1n2.p79 $-89$

Ceva, E., \& Ferretti, M. P. (2018). Political corruption, individual behaviour and the quality of institutions. Politics, Philosophy and Economics, 17(2), 216-231. https://doi.org/10.1177/1470594X177 32067
Esarey, J., \& Schwindt-bayer, L. (2016). Women's Representation, Accountability, and Corruption in Democracies* Version: June 28, 2016 Forthcoming in.

Kaufmann, D. (2016). Corruption Matters, (June).

Poernomo, S. H. (2013). Berani Korupsi Itu Memalukan. Depok: Mizan Media Utama.

Ritaudin, M. S. (2014). Wawasan Etika Politik, Membangun Sikap Kritis dan Rasional Politik Bangsa. Jurnal TAPIs, 10(2), 12-32.

Runi, H. (2017). Etika Politik dalam Negara Demokrasi Oleh: Runi Hariantati. Demokrasi, no 1, 57-68.

Shapiro, I. (2014). Asas Moral dalam Politik. Jakarta: buku obor.

Smith, K., \& Al, E. T. (n.d.). < AT > Intuitive Ethics and Political Orientations : Testing Moral Foundations as a Theory of Political Ideology < AU / AA > Kevin Smith University of Nebraska - Lincoln John Alford Rice University John Hibbing University of Nebraska Lincoln Nicholas G . https://doi.org/10.1111/ajps.12255.Th is

\section{PROFIL SINGKAT}

Nama: Ashari Sakti Alim, S.IP. M.IP

TTL : Tobelo - $01-10-1996$.

Pendidikan : S1 Ilmu Pemerintahan, FISIP, Universitas Langlangbuana Bandung. Lulus tahun 2017.

S2 Magister Ilmu Pemerintahan, Pascasarjana, Universitas Muhammadiyah 
Yogyakarta. Lulus tahun

2020.

Aktivitas yang dilakukan saat ini adalah menulis Jurnal dan Artikel. 